\title{
Pengaruh Pengungkapan Corporate Social Responsibility, Good Corporate Governance dan Sales Growth pada Tax Avoidance
}

\author{
Ni Made Dwi Payanti ${ }^{1}$ \\ Fakultas Ekonomi dan Bisnis \\ Universitas Udayana, Indonesia \\ Email: dwipayanti765@gmail.com
}

\author{
I Ketut Jati ${ }^{2}$ \\ Fakultas Ekonomi dan Bisnis \\ Universitas Udayana, Indonesia
}

\begin{abstract}
ABSTRAK
Penelitianini bertujuan untuk menguji pengaruh pengungkapan corporate social responsibility, good corporate governance dan sales growth pada tax avoidance dengan proksi cash effective tax rate (CETR). Penelitian ini dilakukan pada perusahaan manufaktur yang terdaftar di Bursa Efek Indonesia periode 2015-2018. Penentuan sampel menggunakan metode nonprobability sampling dengan teknik purposive sampling diperoleh sebanyak 20 perusahaan dengan jumlah pengamatan sebanyak 80 pengamatan. Teknik analisis data yang digunakan adalah analisis regresi linear berganda, terlebih dahulu dilakukan analisis faktor untuk menentukan faktor dari variabel good corporate governance. Hasil penelitian ini menunjukkan bahwa pengungkapan corporate social responsibility tidak berpengaruh pada tax avoidance, good corporate governance dengan proksi yang terpilih mewakili adalah kepemilikan manajerial dan kepemilikan institusional berpengaruh nega tif pada tax avoidance, sedangkan sales growth berpengaruh positif pada tax avoidance.
\end{abstract}

Kata Kunci: Tax Avoidance; Pengungkapan Corporate Social Responsibility; Good Corporate Governance; Sales Growth.

\section{The Effects of Corporate Social Responsibility Disclosure, Good Corporate Governance and Sales Growth on Tax Avoidance}

\begin{abstract}
This study aims to examine the effect of corporate social responsibility disclosure, good corporate governance and sales growth on tax avoidance with a cash effective tax rate (CETR) proxy. This research was conducted at manufacturing companies listed on the Indonesia Stock Exchange in the 2015-2018 period. Determination of the sample using the nonprobability sampling method with purposive sampling technique obtained by 20 companies with 80 observations. The data analysis technique used is multiple linear regression analysis, first factor analysis is carried out to determine the factors of good corporate governancevariables. The results of this study indicate that disclosure of corporate social responsibility has no effect on tax avoidance, good corporate governance with proxies selected representing managerial ownership and institutional ownership negatively affect tax avoidance, while sales growth has a positive effect on tax avoidance.
\end{abstract}

Keywords: Tax Avoidance; Corporate Social Responsibility Disclosure; Good Corporate Governance; Sales Growth.

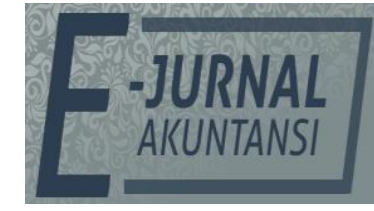

E-JA

e-Jurnal Akuntansi e-ISSN 2302-8556

Vol. 30 No. 5

Denpasar, Mei 2020

Hal.1066-1083

Artikel Masuk:

8 Januari 2020

Tanggal Diterima: 27 Februari 2020 


\section{PENDAHULUAN}

Tax avoidance adalah salah satu cara dari manajemen pajak untuk meminimalisasi pembayaran pajak kepada pemerintah oleh wajib pajak, khususnya perusahaan dari besarnya nominal seharusnya, namun dilakukan secara legal dengan memanfaatkan celah atau loopholes yang ada di dalam perundang-undangan perpajakan (Hoque, 2017). Tax avoidance adalah skema transaksi yang ditujukan untuk mengurangi pembayaran pajak dengan memanfaatkan celah-celah ketentuan perpajakan (Jacob, 2014). Tindakan tax avoidance biasanya mengeksploitasi Undang-Undang perpajakan (Purwantini, 2017). Umumnya, tindakan tax avoidance dikaitakan dengan perencanaan pajak (tax planning) sebagai proses untuk mengatur agar pajak terutang baik pajak penghasilan atau pajak lainnya yang harus dibayar bisa serendah mungkin, selama diizinkan oleh ketentuan Undang-Undang perpajakan (Jingga \& Lina, 2017). Perusahaan yang melakukan tax avoidance dianggap tidak memberikan kontribusi kepada pemerintah dalam rangka membiayai fasilitas publik (Chen et al., 2016). Theory of planned behavior yang dikemukakan oleh Ajzen (1991), mendasari perilaku wajib pajak dalam memenuhi kewajiban perpajakannya. Wajib pajak akan mempunyai rencana untuk melakukan tindakan tax avoidance atau tidak. Wajib pajak yang sadar pajak akan memiliki keyakinan akan pentingnya membayar pajak. Berbeda dengan wajib pajak, yang tidak sadar akan pentingnya membayar pajak, rasionalitasnya akan memengaruhi penentuan perilaku tindakan tax avoidance.

Data target dan realisasi penerimaan pajak yang dipublikasikan pada Laporan Kinerja Direktorat Jendral Pajak (DJP), yang disajikan pada Tabel 1.

Tabel 1. Target dan Realisasi Penerimaan Pajak Tahun 2015-2018 (dalam Triliun Rupiah)

\begin{tabular}{lcccc}
\hline \multicolumn{1}{c}{ Tahun } & 2015 & 2016 & 2017 & 2018 \\
\hline Target Pajak & Rp 1.294,26 & Rp1.355,20 & Rp1.283,57 & Rp1.424,00 \\
$\begin{array}{l}\text { RealisasiPajak } \\
\text { Persentase }\end{array}$ & Rp 1.060,83 & Rp1.105,81 & Rp1.151,03 & Rp1.315,51 \\
PenerimaanPajak & $81,96 \%$ & $81,60 \%$ & $89,67 \%$ & $92,24 \%$ \\
\hline
\end{tabular}

Sumber: Menu Kinerja Penerimaan Portal Direktorat Jendral Pajak, 2019

Berdasarkan Tabel 1. persentase realisasi penerimaan negara yang berasal dari sektor pajak dari tahun 2015 ke tahun 2016 mengalami penurunan sebesar 0,36 persen, namun dari tahun 2016 sampai tahun 2018 persentase realisasi penerimaan pajak terus mengalami peningkatan, dari tahun 2016 ke tahun 2017 mengalami peningkatan sebesar 8,07 persen dan pada tahun 2017 ke tahun 2018 mengalami peningkatan sebesar 2,57 persen, walaupun mengalami peningkatan, realisasi penerimaan pajak belum mampu mencapai target yang ditentukan.

Perusahaan manufaktur di Indonesia masih ada yang berupaya untuk melakukan tindakan tax avoidance yang dapat dilihat dari perusahaanperusahaan yang menerima Surat Ketetapan Pajak Kurang Bayar (SKPKB). Direktorat Jendral Pajak dapat menerbitkan SKPKB apabila dari hasil pemeriksaan ditemukan adanya pajak terutang kurang bayar yang dilakukan oleh perusahaan. Fenomena tax avoidance dapat dilihat dari beberapa perusahaan manufaktur yang menerima SKPKB yang diterbitkan tahun 2018 disajikan pada Tabel 2. 
Tabel 2. Perusahaan Manufaktur yang menerima SKPKB 2018

\begin{tabular}{clc}
\hline No. & \multicolumn{1}{c}{ Perusahaan } & Kurang Bayar (Rupiah) \\
\hline 1 & Indal Alumunium Industry Tbk & 14.888 .727 .984 \\
2 & Duta Pertiwi Nusantara Tbk & 1.238 .704 .544 \\
3 & Impack Pratama Industri Tbk & 7.755 .321 .015 \\
4 & Indospring Tbk & 770.606 .846 \\
5 & Ricky Putra Globalindo Tbk & 10.190 .037 .707 \\
6 & Sekar Bumi Tbk & 4.940 .069 .070 \\
7 & Sekar Laut Tbk & 2.446 .688 .616 \\
8 & Siantar Top Tbk & 20.750 .000 .000 \\
9 & Mandom Indonesia Tbk & 20.235 .572 .361 \\
10 & Wismilak Inti Makmur Tbk & 486.593 .457 \\
\hline Sumber: Data Penelitian, 2019
\end{tabular}

Tabel 2. menunjukkan beberapa perusahaan manufaktur yang menerima SKPKB yang diterbitkan pada tahun 2018. Perusahaan yang menerima SKPKB yaitu Indal Aluminium Industry Tbk., Duta Pertiwi Nusantara Tbk., Impack Pratama Industri Tbk., Indospring Tbk., Ricky Putra Globalindo Tbk., Sekar Bumi Tbk., Sekar Laut Tbk., Siantar Top Tbk., Mandom Indonesia Tbk. dan Wismilak Inti Makmur Tbk. Fenomena penerbitan Surat Ketetapan Pajak Kurang Bayar (SKPKB) ini terjadi karena perusahaan kurang membayar pajak terutangnya dan hal ini mengindikasikan bahwa perusahaan tersebut berusaha melakukan tax avoidance agar lebih sedikit membayar pajak terutangnya yang berdampak pada perekonomian Indonesia (Ayuningtyas \& Sujana, 2018).

Fenomena tindakan tax avoidance dilakukan oleh Astra Internasional Tbk. (ASII) pada tahun 2014, salah satu anak perusahaannya adalah PT. Toyota Motor Manufacturing Indnesia (TMMIN) mengumumkan kinerja ekspor mobil utuh mereka pada tahun lalu. Jumlahnya mencatat rekor yaitu lebih dari 118 ribu unit, yang setara dengan 70 persen total ekspor kendaraan dari Indonesia tahun lalu. Kinerja ekspor mobil tersebut jika ditambah dengan produk mobil terurai dan komponen kendaraan, maka nilai ekspor pabrik mobil yang 95 persen sahamnya dikuasai oleh Toyota Motor Corporation (TMC) Jepang tersebut mencapai US\$ 1,7 miliar atau sekitar Rp 17 triliun. Direktorat Jendral Pajak Kementerian Keuangan memiliki bukti bahwa Toyota Motor Manufacturing memanfaatkan transaksi antar perusahaan terafiliasi di dalam dan luar negeri untuk menghindari pembayaran pajak atau transfer pricing. Modusnya yaitu memindahkan beban keuntungan berlebih dari satu negara ke negara lain yang menerapkan tarif pajak lebih rendah. Pemindahan beban dilakukan dengan memanipulasi harga secara tidak wajar. Terungkap bahwa seribu mobil buatan Toyota Motor Manufacturing Indonesia harus dijual terlebih dahulu ke kantor Toyota Asia Pasifik di Singapura, sebelum dijual ke Filipina dan Thailand. Hal ini dilakukan untuk menghindari membayar pajak yang tinggi di Indonesia (Sugihato, 2014).

Salah satu faktor yang dapat memengaruhi tindakan tax avoidance yang dilakukan oleh perusahaan adalah pengungkapan Corporate Social Responsibility (CSR). Pengungkapan CSR dianggap sebagai suatu cara untuk mengefisienkan beban pajak, serta menjadi salah satu faktor penting dalam keberlangsungan dan kesuksesan suatu perusahaan, karena CSR dapat membangun kepercayaan para stakeholder (Lanis \& Richardson, 2012). Berdasarkan fungsi kebijakan perpajakan 
sebagi instrumen pengatur adalah ketentuan perpajakan Indonesia yang memberikan insentif untuk program-program CSR, yang tertuang dalam UU No. 36 Tahun 2008 tentang Pajak Penghasilan. Kebijakan ini diatur dalam Pasal 6 ayat (1), berupa tax deduction. Beberapa item CSR menjadi pengeluaran yang dapat dibebankan sebagai biaya (deductible expenses), contohnya biaya pengolahan limbah, biaya magang, beasiswa dan pelatihan, sumbangan dalam rangka penanggulangan bencana nasional, sumbangan fasilitas pendidikan dan lain-lain (Femitasari, 2014). Perusahaan yang tidak bertanggung jawab secara sosial akan melakukan strategi pajak yang lebih agresif dan dianggap mempunyai peringkat rendah dalam CSR dibandingkan dengan perusahaan yag sadar sosial (Watson, 2015). Penelitian yang dilakukan oleh Wiguna \& Jati (2017) menyatakan bahwa CSR berpengaruh positif pada penghindaran pajak. Berbeda dengan penelitian yang dilakukan oleh Park (2017) serta Januari \& Suardikha (2019), yang memperoleh hasil bahwa CSR berpengaruh negatif terhadap tax avoidance, sedangkan penelitian yang dilakukan oleh Darmayanti \& Merkusiwati (2019) memperoleh hasil bahwa CSR tidak berpengaruh pada tax avoidance.

Perlu adanya tata kelola perusahaan yang baik atau dikenal dengan istilah Good Corporate Governance (GCG) untuk mengurangi tindakan tax avoidance. Penerapan GCG diharapkan dapat menciptakan pengawasan terhadap kegiatan manajer, sehingga dapat meminimalisasi tindakan tax avoidance yang dilakukan perusahaan (Pradnyawati \& Suprasto, 2019). Penelitian yang dilakukan oleh Lestari \& Putri (2017) memperoleh hasil bahwa corporate governance berpengaruh negatif terhadap penghindaran pajak. Penelitian Jamei (2017), menemukan bahwa komite audit, proporsi komisaris independen dan kepemilikan institusional tidak berpengaruh pada tax avoidance. Berbeda dengan penelitian sebelumnya, penelitian ini menggunakan teknik analisis faktor pada variabel GCG untuk menjelaskan setiap proksi yang akan digunakan sebagai variabel.

Faktor lain yang dapat memengaruhi perusahaan untuk membayar pajak adalah sales growth. Perusahaan dapat mengukur seberapa besar profit yang diterima dari besarnya sales growth. Perusahaan dapat memaksimalkan sumber daya yang dimiliki dengan memperhatikan penjualan pada tahun sebelumnya. Penelitian yang dilakukan oleh Dewinta \& Setiawan (2016), serta Januari \& Suardikha (2019) memperoleh hasil bahwa sales growth berpengaruh positif pada tax avoidance. Berbeda dengan penelitian oleh Ayuningtyas \& Sujana (2018) yang memperoleh hasil bahwa sales growth berpengaruh negatif pada tax avoidance, sedangkan penelitian dari Oktaviyani \& Munandar (2017) memperoleh hasil bahwa sales growth tidak berpengaruh terhadap tax avoidance.

Penelitian ini dilakukan pada perusahaan manufaktur yang terdaftar di Bursa Efek Indonesia periode 2015-2018 dikarenakan perusahaan manufaktur merupakan salah satu wajib pajak yang sering difokuskan dalam pemeriksaan Direktorat Jendral Pajak (Mulyani et al., 2014). Menurut data kemenkeu.go.id mengenai penerimaan pajak dari sektor-sektor usaha utama pada tahun 2018, di mana penerimaan terbesar berasal dari sektor industri pengolahan atau manufaktur dengan jumlah penerimaan sebesar 363,60 triliun rupiah. Kementerian Keuangan mencatat sektor manufaktur memiliki kontribusi terbesar pada penerimaan pajak sektoral yaitu sebesar 30 persen, namun 
mengalami penurunan pertumbuhan. Pada tahun 2018 pertumbuhannya tercatat 11,12 persen lebih rendah sebesar 7,16 persen dibandingkan dengan tahun 2017 yang mampu tumbuh sebesar 18,28 persen.

Tax avoidance diukur menggunakan proksi Cash Effective Tax Rate (CETR). Alasan menggunakan CETR untuk mengukur ada atau tidaknya tax avoidance dikarenakan CETR mengukur secara langsung arus kas keluar yang digunakan untuk pembayaran pajak dibagi dengan laba sebelum pajak (Park, 2018). Tarif pajak efektif berlaku untuk tingkat penghindaran pajak (Thai Ha \& Quyen, 2017). Perbedaan penelitian ini dengan penelitian sebelumnya adalah pada kurun waktu penelitian, pengukuran pengungkapan CSR yang menggunakan ISO 26000 serta menggunakan analisis faktor untuk penentuan proksi GCG. Di antara keempat proksi GCG yaitu, kepemilikan manajerial, kepemilikan institusional, komite audit dan dewan komisaris independen yang akan digunakan sebagai variabel bebas dalam penelitian ini adalah proksi yang memiliki skor tertinggi dalam kemampuan menjelaskan hubungan atau korelasi dengan tax avoidance.

Theory of planned behavior dapat menjelaskan perilaku wajib pajak dalam memenuhi kewajiban perpajakannya. Pengungkapan CSR berkaitan dengan behavioral beliefs yang menjelaskan bahwa sebelum individu melakukan sesuatu, individu tersebut akan memiliki keyakinan mengenai hasil yang akan diperoleh dari perilakunya dan evaluasi atas hasil tersebut. Perilaku yang positif akan menghasilkan hasil yang positif juga (Chen, 2010). Pengungkapan CSR merupakan salah satu aktivitas yang positif dan mendukung keberlangsungan hidup sebuah perusahaan (Lanis \& Richardson, 2011). Perusahaan yang memiliki tingkat aktivitas pengungkapan CSR yang tinggi menunjukkan bahwa perusahaan memiliki rasa tanggung jawab sosial yang tinggi yang dicerminkan dalam sikap patuh dalam membayar beban pajak atau tidak melakukan tindakan tax avoidance. Dalam teori legitimasi disebutkan hubungan antara perusahaan dengan sosial yaitu masyarakat, pemerintah, individu dan kelompok masyarakat. Perusahaan yang telah menyesuaikan operasionalnya dengan nilai dan norma sosial yang berlaku akan mendapatkan pengakuan atau legitimasi, sehingga memperoleh citra positif. Perusahaan bisa mewujudkan tanggung jawab sosial kepada masyarakat melalui pemerintah dengan cara membayar beban pajak sesuai dengan kewajibannya dan tidak melakukan tindakan tax avoidance. Pengungkapan CSR dapat memengaruhi tindakan tax avoidance yang dilakukan perusahaan, karena terdapat sejumlah biaya terkait dengan program CSR yang diperkenankan sebagai deductible expense dalam menghitung penghasilan kena pajak seperti biaya pengolahan limbah, biaya magang, beasiswa dan pelatihan, sumbangan dalam rangka penanggulangan bencana nasional, sumbangan fasilitas pendidikan dan lain-lain (Femitasari, 2014). Adanya biaya-biaya yang dikeluarkan terkait program CSR akan mengurangi laba perusahaan, yang berakibat pada kecilnya beban pajak yang dibayarkan perusahaan, sehingga perusahaan meminimalisasi tindakan tax avoidance (Pradipta \& Supriyadi, 2015). Penelitian lainnya yang dilakukan oleh Januari \& Suardikha (2019), serta Dewanti \& Sujana (2019) memperoleh hasil bahwa corporate social responsibility berpengaruh negatif pada tax avoidance. Berdasarkan uraian di atas, maka hipotesis dalam penelitian ini sebagai berikut.

$\mathrm{H}_{1}$ : Pengungkapan Corporate Social Responsibility berpengaruh negatif pada Tax. 


\section{Avoidance.}

Theory of planned behavior menjelaskan bahwa perilaku individu terhadap perilaku tertentu diakibatkan oleh niat seorang individu. Niat tersebut muncul dari beberapa faktor, salah satunya yaitu kontrol keperilakuan (control beliefs). GCG dapat menimbulkan kontrol yang mempersulit perilaku tax avoidance yang ditunjukkan melalui CETR perusahaan yang tinggi. Adanya praktik GCG yang berjalan dengan baik akan mempersulit pihak manajemen untuk melakukan hal yang merugikan perusahaan atau dengan kata lain akan mendorong manajemen untuk tidak bertindak agresif dalam pengelolaan beban pajaknya dengan tujuan meningkatkan kinerja perusahaan (Lestari \& Putri, 2017). Penerapan GCG dapat memengaruhi keputusan-keputusan strategis perusahaan, sehingga dapat menjaga keseimbangan agar tercapai tujuan perusahaan. Menurut Fadhilah (2014) mekanisme dalam pengawasan GCG ada dua yaitu mekanisme internal dan eksternal. Dengan adanya mekanisme internal dan mekanisme eksternal akan meningkatkan pengawasan terhadap aktivitas yang dilakukan perusahaan, serta mendorong perusahaan untuk tidak bertindak agresif dalam pengelolaan beban pajak dengan tujuan meningkatkan kinerja perusahaan. Semakin baik penerapan GCG, maka ketaatan perusahaan akan semakin meningkat, sehingga tingkat tax avoidance yang dilakukan lebih rendah yang dicerminkan dengan nilai CETR yang tinggi. Berdasarkan penelitian yang dilakukan oleh Praditasari \& Setiawan (2017) yang menghubungkan GCG dengan proksi kepemilikan institusional, komisaris independen dan komite audit pada tax avoidance memperoleh hasil bahwa kepemilikan institusional dan komite audit berpengaruh negatif pada tax avoidance. Penelitian yang dilakukan oleh Fadhila et al. (2017) memperoleh hasil bahwa kepemilikan manajerial dan komite audit memiliki pengaruh signifikan negatif terhadap tax avoidance. Berdasarkan uraian di atas, maka hipotesis dalam penelitian ini sebagai berikut.

$\mathrm{H}_{2}$ : Good Corporate Governance berpengaruh negatif pada Tax Avoidance.

Theory of planned behavior dapat menjelaskan perilaku wajib pajak dalam memenuhi kewajiban perpajakannya. Sales growth berkaitan dengan behavioral beliefs yang menjelaskan bahwa sebelum individu melakukan sesuatu, individu tersebut akan memiliki keyakinan mengenai hasil yang akan diperoleh dari perilakunya dan evaluasi atas hasil tersebut. Perilaku yang positif akan menghasilkan hasil yang positif juga (Chen, 2010). Ketika perusahaan mengetahui dengan pertumbuhan penjualan yang meningkat akan mendapatkan profit atau laba yang besar, maka perusahaan akan merencanakan perilaku yang taat dan patuh membayar pajak, karena perusahaan dianggap mampu secara finansial membayar beban pajaknya dan menghindari sanksi atau denda yang justru akan merugikan perusahaan, sehingga akan mengarah negatif pada tindakan tax avoidance. Penelitian yang dilakukan oleh Ayuningtyas \& Sujana (2018), yang menyatakan bahwa sales growth berpengaruh negatif pada tax avoidance yang artinya semakin tinggi pertumbuhan penjualan, maka semakin berkurang aktivitas tax avoidance suatu perusahaan yang disebabkan karena perusahaan dengan tingkat penjualan yang relatif besar akan memberikan peluang untuk memperoleh laba yang besar dan mampu untuk melakukan pembayaran pajak. Berdasarkan uraian di atas, maka hipotesis dalam penelitian ini sebagai berikut. 
$\mathrm{H}_{3}$ : Sales Growth berpengaruh negatif pada Tax Avoidance.

\section{METODE PENELITIAN}

Lokasi penelitian ini dilakukan di perusahaan manufaktur yang terdaftar di Bursa Efek Indonesia (BEI) periode tahun 2015-2018 dengan mengakses data perusahaan berupa informasi laporan keuangan pada situs resminya di www.idx.co.id dan mengakses daftar perusahaan melalui www.sahamok.com. Objek penelitian pada penelitian ini adalah pengungkapan corporate social responsibility $\left(\mathrm{X}_{1}\right)$, good corporate governance $\left(\mathrm{X}_{2}\right)$, sales growth $\left(\mathrm{X}_{3}\right)$ dan tax avoidance (Y). Perusahaan yang diteliti adalah perusahaan manufaktur yang terdaftar di Bursa Efek Indonesia periode 2015-2018. Populasi dalam penelitian ini adalah seluruh perusahaan manufaktur yang terdaftar di Bursa Efek Indonesia (BEI) pada periode 2015-2018 yang berjumlah sebanyak 168 perusahaan. Sampel pada penelitian ini adalah 20 perusahaan manufaktur yang dipilih dengan menggunakan metode nonprobability sampling dengan teknik purposive sampling di Bursa Efek Indonesia (BEI) periode 2015-2018.

Tax avoidance merupakan penghematan pajak yang timbul dengan memanfaatkan ketentuan perpajakan yang dilakukan secara legal untuk meminimalkan kewajiban pajak (Lim, 2011). Rumus untuk menghitung CETR dalam penelitian ini menggunakan model yang dikembangkan oleh Hanlon \& Heitzman (2010) yaitu sebagai berikut.

CETR $=\frac{\text { Cash } T a x \text { Paidi,t }}{\text { Pretax Income i,t }}$

Pengungkapan corporate social responsibility (CSR) merupakan kegiatan perusahaan yang memiliki tujuan untuk membangun hubungan yang baik dengan masyarakat, yaitu dengan cara melakukan kegiatan yang sesuai dengan nilai dan norma, serta kebutuhan masyarakat. Adapun pengukurannya menggunakan rumus (Kusumawardani, 2017).

$C S R D I=\frac{\text { Jumlah item informasi CSR yang diungkapkan }}{\text { Jumlah iteminformasi CSR menurut ISO } 26000}$

Teknik analisis data yang digunakan dalam penelitian ini adalah teknik analisis regresi linear berganda. Adapun model regresi linear berganda dalam penelitian ini dinyatakan dengan persamaan sebagai berikut.

$$
Y=\alpha+\beta_{1} . X_{1}+\beta_{2} . X_{2}+\beta_{3} . X_{3}+\text { e. }
$$

Keterangan :

\begin{tabular}{|c|c|}
\hline Y & $=$ Tax Avoidance \\
\hline a & $=$ Konstanta \\
\hline$\beta_{1}, \beta_{2,}, \beta_{3}$ & $=$ Koefisien Regresi dari masing-masing variabel \\
\hline$X_{1}$ & $=$ Pengungkapan Corporate Social Responsibility \\
\hline$X_{2}$ & $=$ Good Corporate Governance \\
\hline$X_{3}$ & $=$ Sales Growth \\
\hline & $=$ error \\
\hline
\end{tabular}

\section{HASIL DAN PEMBAHASAN}

Analisis faktor dalam penelitian ini menggunakan jenis analisis faktor konfirmatori yang bertujuan untuk mengkonfirmasi struktur faktor yang dianalisis berdasarkan konsep atau teori dalam penelitian ini yaitu good corporate governance (GCG). Variabel GCG digunakan sebagai variabel independen 
menggunakan empat proksi yaitu kepemilikan manajerial, kepemilikan institusional, komite audit dan dewan komisaris independen. Keempat proksi tersebut selanjutnya difaktorkan untuk mengelompokkan proksi ke dalam satu faktor. Rangkuman hasil analisis faktor konfirmatori pada penelitian ini tersaji sebagai berikut.

Tabel 3. Hasil Nilai Validitas dalam Analisis Faktor pada Analisis 1

\begin{tabular}{lc}
\hline \multicolumn{1}{c}{ Kriteria Penilaian } & Nilai \\
\hline KMO (Kaiser-Meyer-Olkin) & 0,459 \\
$\chi^{2}$ (Chi Square) & 81,259 \\
Significance Probability & 0,000 \\
Anti Image & \\
KPMJ & 0,479 \\
INST & 0,471 \\
KA & 0,383 \\
DKI & 0,441 \\
\hline
\end{tabular}

Sumber: Data Penelitian, 2019

Pada Tabel 3. menunjukkan bahwa hasil uji KMO sebesar 0,459 lebih kecil dari 0,50 dan Bartlett's tes Sphericity signifikan sebesar 0,000. Jadi, disimpulkan bahwa analisis faktor belum bisa dilanjutkan. Hasil anti image correlation menunjukkan bahwa keempat proksi GCG memiliki nilai anti image correlation lebih kecil dari 0,50 dan belum layak digunakan untuk analisis faktor, maka solusinya dengan mengeliminasi proksi komite audit dari analisis karena memiliki korelasi terkecil yaitu 0,383. Langkah selanjutnya melakukan analisis dengan proksi KPMJ, INST, DKI, hasilnya terlihat pada Tabel 4.

Tabel 4. Hasil Nilai Validitas dalam Analisis Faktor pada Analisis 2

\begin{tabular}{lc}
\multicolumn{1}{c}{ Kriteria Penilaian } & Nilai \\
\hline KMO (Kaiser-Meyer-Olkin) & 0,501 \\
$\chi^{2}$ (Chi Square) & 68,017 \\
Significance Probability & 0,000 \\
Anti Image & \\
$\quad$ KPMJ & 0,501 \\
$\quad$ INST & 0,501 \\
DKI & 0,503 \\
\hline
\end{tabular}

Sumber: Data Penelitian, 2019

Pada Tabel 4. terlihat bahwa hasil uji KMO sebesar 0,501 lebih besar atau sama dengan 0,50 dan Bartlett's tes Sphericity signifikan sebesar 0,000. Jadi, disimpulkan bahwa analisis faktor dapat diteruskan. Hasil analisis 2 menunjukkan bahwa tiga dari proksi GCG tidak ada yang memiliki anti image correlation lebih kecil dari 0,50, namun kemampuan menjelaskan variabel GCG yang ditunjukkan oleh angka communalities dari ketiga proksi GCG ada yang memiliki angka lebih kecil dari 0,50 sehingga harus dieliminasi dari analisis. Adapun analisis komponen faktor variabel GCG ditunjukkan pada Tabel 5.

Tabel 5. Analisis Komponen Faktor Variabel Good Corporate Governance

\begin{tabular}{lcc}
\hline \multicolumn{3}{c}{ Good Corporate Governance } \\
\hline Proksi & Factor Loading & Communalities \\
\hline Kepemilikan Manajerial & $-0,858$ & 0,736 \\
Kepemilikan Institusional & 0,924 & 0,854 \\
Dewan Komisaris Independen & 0,529 & 0,280 \\
\hline
\end{tabular}

Sumber: Data Penelitian, 2019 
Proksi dewan komisaris independen yang memiliki nilai communalities terkecil harus dieliminasi, kemudian analisis faktor kembali dilakukan dengan hanya menyertakan dua proksi yaitu kepemilikan manajerial dan kepemilikan institusional. Hasil analisis faktor setelah mengeliminasi dewan komisaris independen disajikan sebagai berikut.

Tabel 6. Hasil Nilai Validitas dalam Analisis Faktor pada Analisis 3

\begin{tabular}{lc}
\hline \multicolumn{1}{c}{ Kriteria Penilaian } & Nilai \\
\hline KMO (Kaiser-Meyer-Olkin) & 0,500 \\
$\chi^{2}$ (Chi Square) & 56,166 \\
Significance Probability & 0,000 \\
Anti Image & \\
$\quad$ KPMJ & 0,500 \\
$\quad$ INST & 0,500 \\
\hline
\end{tabular}

Sumber: Data Penelitian, 2019

Berdasarkan Tabel 6. terlihat bahwa hasil uji KMO sebesar 0,500 lebih besar atau sama dengan 0,50 dan Bartlett's tes Sphericity signifikan sebesar 0,000. Jadi, disimpulkan bahwa sudah memiliki kecukupan sampel untuk analisis faktor dan dapat diteruskan. Hasil analisis 3 menunjukkan bahwa proksi GCG yang terdiri dari kepemilikan manajerial dan kepemilikan institusional tidak ada yang memiliki anti image correlation lebih kecil dari 0,50, sehingga kedua proksi GCG tersebut memenuhi syarat dan layak digunakan dalam analisis faktor.

Tabel 7. Hasil Uji Total Variance Explained Variabel GCG Setelah Komite Audit dan Dewan Komisaris Independen Dikeluarkan

\begin{tabular}{ccccccc}
\hline Component & \multicolumn{3}{c}{ Initial Eigenvalues } & Extraction Sums of Squared Loadings \\
\cline { 2 - 7 } & Total & $\begin{array}{c}\text { \% of } \\
\text { variance }\end{array}$ & $\begin{array}{c}\text { Cumulative } \\
\%\end{array}$ & Total & $\begin{array}{c}\% \text { of } \\
\text { variance }\end{array}$ & $\begin{array}{c}\text { Cumulative } \\
\%\end{array}$ \\
\hline 1 & 1,718 & 85,901 & 85,901 & 1,718 & 85,901 & 85,901 \\
2 & 0,282 & 14,099 & 100,000 & & & \\
\hline
\end{tabular}

Sumber: Data Penelitian, 2019

Total initial eigen value menunjukkan kepentingan relatif masing-masing faktor dalam menghitung varians masing-masing indikator yang akan dianalisis. Berdasarkan Tabel 7. menunjukkan bahwa faktor yang diperoleh dengan eigen value (setelah proksi komite audit dan dewan komisaris independen dikeluarkan) lebih besar dari satu dan persentase varians kumulatif yang bisa dijelaskan sebesar 85,901 persen. Berdasarkan kriteria validitas analisis faktor yaitu nilai varians harus lebih besar atau sama dengan 60 persen, sehingga dapat disimpulkan bahwa variabel GCG yang diteliti valid dan skor faktor yang diperoleh layak digunakan untuk analisis berikutnya.

Tabel 8. Analisis Komponen Faktor Variabel Good Corporate Governance

\begin{tabular}{lcc}
\hline \multicolumn{3}{c}{ Good Corporate Governance } \\
\hline Proksi & Factor Loading & Communalities \\
\hline Kepemilikan Manajerial & $-0,927$ & 0,859 \\
Kepemilikan Institusional & 0,927 & 0,859 \\
\hline
\end{tabular}

Sumber: Data Penelitian, 2019

Kemampuan menjelaskan variabel GCG ditunjukkan oleh angka communalities seperti yang disajikan pada Tabel 8. angka communalities kepemilikan manajerial dan kepemilikan institusional yaitu sebesar 0,859 . Angka tersebut menunjukkan sekitar 85,9 persen varians dari kepemilikan manajerial 
dan kepemilikan institusional dapat dijelaskan oleh faktor GCG yang terbentuk. Nilai communalities dari kedua proksi tersebut lebih besar dari 0,50, hal ini menunjukkan kedua proksi tersebut dapat digunakan untuk mewakili faktor GCG. Berdasarkan hasil analisis faktor diperoleh dua proksi yang terpilih untuk mewakili faktor GCG yaitu kepemilikan manajerial dan kepemilikan institusional yang dipercaya memiliki kemampuan untuk mempengaruhi kinerja perusahaan.

Analisis statistik deskriptif adalah gambaran atau deskripsi data yang dilihat dari nilai maksimum, nilai minimum, nilai rata-rata (mean), dan standar deviasi. Deskripsi variabel dalam penelitian dilakukan pada variabel pengungkapan corporate social responsibility (CSR), good corporate governance (GCG), sales growth dan tax avoidance. Hasil uji statistik deskriptif disajikan pada Tabel 9.

Tabel 9. Hasil Uji Statistik Deskriptif

\begin{tabular}{lccccc}
\hline & $\mathrm{N}$ & Minimum & Maximum & Mean & Std. Deviation \\
\hline Tax Avoidance & 80 & 0,1395 & 0,6487 & 0,325957 & 0,1032895 \\
Pengungkapan & 80 & 0,2432 & 0,7027 & 0,433027 & 0,1100007 \\
CSR & & & & & \\
GCG & 80 & $-1,2739$ & 3,1886 & 0,000000 & 1,0000000 \\
Sales Growth & 80 & $-0,2990$ & 0,4834 & 0,059553 & 0,1207889 \\
Valid N (listwise) & 80 & & & & \\
\hline Sumber: Data Pen & & &
\end{tabular}

Sumber: Data Penelitian, 2019

Tax avoidance pada penelitian ini diproksikan dengan cash effective tax rates (CETR). Berdasarkan hasil uji statistik deskriptif, diperoleh nilai minimum sebesar 0,1395 pada Alkindo Naratama Tbk di periode pengamatan tahun 2018 dan nilai maksimum sebesar 0,6487 pada Tempo Scan Pacific Tbk di periode pengamatan tahun 2016. Variabel tax avoidance memiliki nilai rata-rata sebesar 0,325957. Hal ini menunjukkan bahwa nilai rata-rata kas pajak dalam suatu perusahaan sebesar 32,5957 persen dari laba sebelum pajaknya. Rata-rata pembayaran pajak perusahaan yang cukup tinggi ini menunjukkan tindakan tax avoidance yang dilakukan perusahaan masih tergolong rendah. Standar deviasi tax avoidance sebesar 0,1032895, nilai ini lebih rendah dibandingkan dengan nilai rata-rata, hal ini menunjukkan bahwa sebaran data tax avoidance sudah merata.

Berdasarkan hasil uji statistik deskriptif, variabel pengungkapan CSR memiliki nilai minimum sebesar 0,2432 pada Indal Aluminium Industry Tbk di periode pengamatan tahun 2015 dan 2016. Nilai maksimum sebesar 0,7027 pada Astra International Tbk di periode pengamatan tahun 2018. Variabel pengungkapan CSR memiliki nilai rata-rata sebesar 0,433027 yang lebih mendekati nilai minimum yang artinya bahwa perusahaan yang dijadikan sampel lebih sedikit mengungkapkan CSR. Standar deviasi pengungkapan CSR sebesar 0,1100007 nilai ini lebih rendah dibandingkan dengan nilai rata-rata, hal ini menunjukkan bahwa sebaran data pengungkapan CSR sudah merata.

Good corporate governance dalam penelitian ini diproksikan dengan kepemilikan manajerial dan kepemilikan institusional sesuai dengan hasil analisis faktor yang telah dilakukan. Nilai minimum faktor GCG sebesar -1,2739 pada Sekar Laut Tbk di periode pengamatan tahun 2015. Nilai maksimum faktor GCG sebesar 3,1886 pada Wismilak Inti Makmur Tbk di periode pengamatan 
tahun 2017. Nilai rata-rata faktor GCG sebesar 0,000000, sedangkan standar deviasi sebesar 1,0000000 yang berarti adanya penyimpangan antara nilai faktor GCG dengan nilai rata-ratanya yaitu sebesar 1,0000000.

Berdasarkan hasil uji statistik deskriptif, variabel sales growth memiliki nilai minimum sebesar -0,2990 pada Lionmesh Prima Tbk di periode pengamatan tahun 2015. Variabel sales growth memiliki nilai maksimum sebesar 0,4834 pada Indal Aluminium Industry Tbk di periode pengamatan tahun 2016. Variabel sales growth memiliki nilai rata-rata sebesar 0,059553 , hal ini menunjukkan bahwa sales growth perusahaan tergolong cukup tinggi. Nilai standar deviasi yaitu sebesar 0,1207889 yang berarti adanya penyimpangan antara nilai sales growth dengan nilai rata-ratanya yaitu sebesar 0,1207889 .

Analisis regresi linear berganda ini digunakan untuk menganalisis pengaruh Pengungkapan corporate social responsibility $\left(\mathrm{X}_{1}\right)$, good corporate governance $\left(\mathrm{X}_{2}\right)$ dan sales growth $\left(\mathrm{X}_{3}\right)$ pada tax avoidance $(\mathrm{Y})$. Analisis regresi linear berganda diolah dengan bantuan software SPSS 22 for Windows dengan hasil yang dapat dilihat pada Tabel 10.

Tabel 10. Hasil Analisis Regresi Linear Berganda

\begin{tabular}{|c|c|c|c|c|c|c|}
\hline \multicolumn{2}{|c|}{ Model } & \multicolumn{2}{|c|}{$\begin{array}{l}\text { Unstandardized } \\
\text { Coefficients }\end{array}$} & \multirow{2}{*}{$\begin{array}{c}\begin{array}{c}\text { Standardized } \\
\text { Coefficients }\end{array} \\
\text { Beta }\end{array}$} & \multirow{2}{*}{$\mathrm{t}$} & \multirow{2}{*}{ Sig. } \\
\hline & & B & $\begin{array}{l}\text { Sta. } \\
\text { Error }\end{array}$ & & & \\
\hline \multirow[t]{5}{*}{1} & (Constant) & 0,408 & 0,048 & & 8,480 & 0,000 \\
\hline & Pengungkapan CSR & $-0,165$ & 0,108 & $-0,175$ & $-1,521$ & 0,132 \\
\hline & Good Corporate & 0,025 & 0,012 & 0,246 & 2,099 & 0,039 \\
\hline & Governance & & & & & \\
\hline & Sales Growth & $-0,188$ & 0,093 & $-0,220$ & $-2,014$ & 0,048 \\
\hline \multicolumn{6}{|c|}{ R Square } & 0,126 \\
\hline \multicolumn{6}{|c|}{ Adjusted } & 0,092 \\
\hline \multicolumn{7}{|c|}{ R Square } \\
\hline \multicolumn{6}{|c|}{ F Statistik } & 3,664 \\
\hline \multicolumn{6}{|c|}{ Signifikansi } & 0,016 \\
\hline
\end{tabular}

Sumber: Data Penelitian, 2019

Berdasarkan hasil analisis regresi linear berganda pada Tabel 10. maka dapat dibuat persamaan regresi sebagai berikut.

$$
\mathrm{Y}=0,408-0,165 \mathrm{X}_{1}+0,025 \mathrm{X}_{2}-0,188 \mathrm{X}_{3}
$$

Nilai konstanta sebesar 0,408 , menunjukkan bahwa apabila nilai pengungkapan CSR, good corporate governance, dan sales growth sama dengan nol, maka nilai tax avoidance akan meningkat sebesar 0,408 satuan. Nilai koefisien $\beta 1$ sebesar -0,165, menunjukkan jika nilai pengungkapan CSR (X1) meningkat sebesar 1 satuan, maka CETR sebagai proksi tax avoidance menurun sebesar 0,165 satuan dengan asumsi variabel independen lainnya konstan. Semakin rendah nilai CETR, mencerminkan semakin tingginya tingkat tax avoidance dan sebaliknya, sehingga penurunan nilai CETR perusahaan, menunjukkan peningkatan tindakan tax avoidance (Y) yang dilakukan perusahaan. Nilai koefisien $\beta 2$ sebesar 0,025 , menunjukkan jika nilai good corporate governance (X2) meningkat sebesar 1 satuan, maka CETR sebagai proksi tax avoidance meningkat sebesar 0,025 satuan dengan asumsi variabel independen lainnya konstan. Semakin rendah nilai CETR, mencerminkan semakin tingginya tingkat tax 
avoidance dan sebaliknya, sehingga peningkatan nilai CETR perusahaan menunjukkan rendahnya tingkat tax avoidance $(\mathrm{Y})$. Nilai koefisien $\beta 3$ sebesar 0,188 , menunjukkan jika nilai sales growth (X3) meningkat sebesar 1 satuan, maka CETR sebagai proksi tax avoidance menurun sebesar 0,188 satuan dengan asumsi variabel independen lainnya konstan. Semakin rendah nilai CETR, mencerminkan semakin tingginya tingkat tax avoidance dan sebaliknya, sehingga penurunan nilai CETR perusahaan, menunjukkan peningkatan tindakan tax avoidance $(\mathrm{Y})$ yang dilakukan perusahaan.

Uji koefisien determinasi $\left(\mathrm{R}^{2}\right)$ digunakan untuk mengetahui dan mengukur kemampuan model dalam menerangkan variasi variabel independen. Hasi uji pada Tabel 10. menunjukkan bahwa besarnya nilai Adjusted $R$ Square sebesar 0,092 memiliki arti bahwa sebesar 9,2 persen variasi tax avoidance dapat dijelaskan oleh variabel pengungkapan CSR $\left(\mathrm{X}_{1}\right)$, good corporate governance $\left(\mathrm{X}_{2}\right)$, dan sales growth $\left(\mathrm{X}_{3}\right)$. Sisanya sebesar 90,8 persen dipengaruhi oleh variabel lain yang tidak dimasukkan dalam model penelitian ini.

Uji kelayakan model regresi atau uji $\mathrm{F}$ bertujuan untuk mengetahui apakah semua variabel independen yang diidentifikasi (pengungkapan CSR, good corporate governance, dan sales growth) layak digunakan untuk memprediksi variabel dependen (tax avoidance). Hasil uji $\mathrm{F}$ (F test) pada Tabel 10. menunjukkan bahwa nilai $F$ hitung sebesar 3,664 dengan nilai signifikansi P value 0,016 yang lebih kecil dari $\alpha=0,05$, ini berarti model yang digunakan pada penelitian ini adalah layak. Hal ini berarti model dapat digunakan untuk analisis lebih lanjut.

Hipotesis pertama menyatakan bahwa pengungkapan corporate social responsibility berpengaruh negatif pada tax avoidance. Tabel 10. menunjukkan bahwa nilai koefisien pengungkapan corporate social responsibility sebesar -0,165 dengan nilai signifikansi sebesar 0,132 lebih besar dari $a=0,05$. Hasil ini menunjukkan bahwa pengungkapan corporate social responsibility tidak berpengaruh pada CETR. Artinya, semakin banyak atau sedikitnya pengungkapan corporate social responsibility tidak berpengaruh pada tax avoidance. Hasil pengujian ini tidak dapat mendukung hipotesis pertama yang menyatakan pengungkapan corporate social responsibility berpengaruh negatif pada tax avoidance.

Informasi CSR yang diungkapkan dalam laporan tahunan perusahaan belum tentu sesuai dengan kondisi yang sebenarnya, sehingga tidak bisa dijadikan jaminan bahwa perusahaan yang bertanggung jawab secara sosial tersebut memiliki kecenderungan melakukan tindakan tax avoidance lebih rendah (Makhfudloh, 2018). Kontrol dari pihak yang berwenang terhadap pelaporan CSR belum ada, sehingga kebenaran dari informasi yang dilaporkan oleh perusahaan terkait pengungkapan CSR belum dapat dipertanggungjawabkan (Ulfa, 2016).

Hasil penelitian ini tidak dapat mendukung theory of planned behavior khususnya behavioral beliefs yang menjelaskan bahwa sebelum individu melakukan sesuatu, individu tersebut akan memiliki keyakinan mengenai hasil yang akan diperoleh dari perilakunya dan evaluasi atas hasil tersebut. Perilaku yang positif akan menghasilkan hasil yang positif juga (Chen, 2010). Pengungkapan CSR merupakan salah satu aktivitas yang positif dan penting yang mendukung keberlangsungan hidup sebuah perusahaan (Lanis \& 
Richardson, 2011). Perusahaan yang memiliki tingkat aktivitas pengungkapan CSR yang tinggi menunjukkan bahwa perusahaan memiliki rasa tanggung jawab sosial yang tinggi yang dicerminkan dalam sikap patuh dalam membayar beban pajak yang telah ditetapkan atau dengan tidak melakukan tindakan tax avoidance.

Hasil penelitian ini juga tidak dapat mendukung teori legitimasi yang menyebutkan hubungan antara perusahaan dengan sosial yaitu masyarakat, pemerintah, individu dan kelompok masyarakat. Perusahaan yang telah menyesuaikan operasionalnya dengan nilai dan norma sosial yang berlaku akan mendapatkan pengakuan atau legitimasi, sehingga memperoleh citra positif. Pengungkapan CSR yang dilakukan oleh perusahaan merupakan salah cara untuk mendapatkan citra yang positif dari masyarakat. Perusahaan bisa mewujudkan tanggung jawab sosial kepada masyarakat melalui pemerintah dengan cara membayar beban pajak sesuai dengan kewajibannya dan meminimalisasi tindakan tax avoidance.

Hasil penelitian ini sejalan dengan penelitian dari Darmayanti \& Merkusiwati (2019) yang menyatakan bahwa pengungkapan CSR tidak berpengaruh pada tax avoidance, banyak sedikitnya item CSR yang diungkapkan oleh perusahaan tidak mempunyai pengaruh terhadap tindakan tax avoidance yang dilakukan perusahaan. Hasil penelitian ini juga sejalan dengan penelitian Ramila et al. (2016) yang menyatakan bahwa antara CSR dengan agresivitas pajak tidak mempunyai hubungan yang signifikan, hal ini dikarenakan pengungkapan CSR yang dilakukan oleh perusahaan bukan bertujuan untuk meminimalkan beban pajak dengan memanfaatkan biaya-biaya yang harus dikeluarkan akibat aktivitas CSR yang diperkenankan oleh pajak sebagai beban yang akan mengurangi laba perusahaan dan mengakibatkan kecilnya pembayaran pajak yang ditanggung perusahaan, tetapi perusahaan melakukan pengungkapan CSR untuk melaksanakan tanggung jawabnya terhadap masyarakat yang terkena dampak aktivitas operasi perusahaan dan untuk mendapatkan reputasi baik di mata investor dan masyarakat.

Hipotesis kedua menyatakan good corporate governance berpengaruh negatif pada tax avoidance. Tabel 10. menunjukkan bahwa nilai koefisien good corporate governance sebesar 0,025 dengan nilai signifikansi sebesar 0,039 lebih kecil dari $\alpha=0,05$. Hasil ini menunjukkan bahwa good corporate governance berpengaruh positif pada CETR. Nilai koefisien regresi $\beta_{2}$ sebesar 0,025 menunjukkan hubungan positif antara good corporate governance dengan CETR. Semakin tinggi good corporate governance yang diterapkan perusahaan, maka nilai CETR perusahaan akan meningkat. Hal ini berarti good corporate governance berpengaruh negatif pada tax avoidance. Semakin tinggi good corporate governance yang diterapkan perusahaan, maka semakin rendah tingkat tax avoidance perusahaan, sehingga hipotesis kedua diterima.

Hasil penelitian ini mengkonfirmasi theory of planned behavior yang menjelaskan bahwa perilaku individu terhadap perilaku tertentu diakibatkan oleh niat seorang individu. Niat tersebut muncul dari beberapa faktor, salah satunya yaitu kontrol keperilakuan (control beliefs). GCG dapat menimbulkan kontrol yang mempersulit perilaku tax avoidance yang ditunjukkan melalui CETR perusahaan yang tinggi. Adanya praktik GCG yang berjalan dengan baik akan mempersulit pihak manajemen untuk melakukan hal yang merugikan 
perusahaan. GCG dalam penelitian ini diwakili oleh kepemilikan manajerial dan kepemilikan institusional yang berarti proksi mampu mengontrol perilaku manajemen dalam melakukan tindakan tax avoidance.

Hasil penelitian ini mendukung penelitian dari Fadhila et al. (2017), serta Charisma \& Dwimulyani (2019), yang memperoleh pengaruh negatif antara kepemilikan manajerial pada tax avoidance. Besarnya kepemilikan saham yang dimiliki oleh pihak manajerial menyebabkan pihak manajemen diikutsertakan berperan sebagai pengawas dan pengendali, sehingga akan bersikap lebih hatihati dalam mengambil keputusan, agar keputusan yang dibuat tidak berdampak buruk terhadap sahamnya, termasuk keputusan untuk melakukan tax avoidance yang mengandung risiko di masa depan. Proksi kedua yang mewakili GCG adalah kepemilikan institusional juga mampu mengontrol perilaku manajemen dalam melakukan tindakan tax avoidance. Penelitian yang dilakukan oleh Praditasari \& Setiawan (2017), serta Charisma \& Dwimulyani (2019) yang memperoleh pengaruh negatif antara kepemilikan institusional pada tax avoidance. Semakin tingginya kepemilikan institusional yang dimiliki perusahaan, menandakan semakin tingginya kontrol atau pengawasan terhadap segala kebijakan khususnya terkait keputusan perpajakan yang diambil oleh manajemen selaku pengelola perusahaan dan mampu meminimalisasi tindakan tax avoidance. Kepemilikan institusional berperan untuk mengontrol perilaku manajer dan memaksa manajer untuk lebih berhati-hati dalam mengambil keputusan yang oportunistik.

Hipotesis ketiga menyatakan sales growth berpengaruh negatif pada tax avoidance. Tabel 10. menunjukkan bahwa nilai koefisien sales growth sebesar -0,188 dengan nilai signifikansi sebesar 0,048 lebih kecil dari $a=0,05$. Hasil ini menunjukkan bahwa sales growth berpengaruh pada CETR sebagai proksi tax avoidance. Nilai koefisien regresi $\beta_{3}$ sebesar $-0,188$ menunjukkan hubungan negatif antara sales growth dengan CETR. Semakin besar tingkat sales growth, maka nilai CETR semakin rendah. Artinya, semakin tinggi sales growth perusahaan, maka tax avoidance perusahaan meningkat, sehingga hipotesis ketiga ditolak.

Berdasarkan theory of planned behavior khususnya behavioral beliefs yang menjelaskan bahwa keyakinan individu akan hasil dari suatu perilaku dan evaluasi atas hasil tersebut. Keyakinan dan evaluasi terhadap hasil ini membentuk variabel sikap (attitude). Pertumbuhan penjualan yang meningkat memungkinkan perusahaan untuk meningkatkan ka pasitas operasi perusahaan, karena dengan peningkatan pertumbuhan penjualan secara tidak langsung akan meningkatkan laba. Perusahaan dengan laba yang besar cenderung akan melakukan perencanaan pajak dengan semaksimal mungkin, sehingga dapat mengurangi pembayaran pajak yang harus ditanggung (Puspita \& Febrianti, 2017). Pertumbuhan penjualan yang meningkat meyakini manajer untuk melakukan tindakan tax avoidance yang dapat menghemat besarnya jumlah pajak perusahan.

Hasil penelitian ini sejalan dengan penelitian dari Dewinta \& Setiawan (2016), serta Januari \& Suardikha (2019) yang menyatakan bahwa sales growth berpengaruh positif pada tax avoidance. Sales growth yang meningkat akan meningkatkan praktik tax avoidance. Dengan pertumbuhan penjualan yang 
meningkat, perusahaan akan memperoleh profit yang meningkat. Profit yang tinggi berdampak pada jumlah pembayaran pajak yang harus ditanggung lebih besar, sehingga perusahaan cenderung melakukan tindakan tax avoidance untuk mengurangi jumlah pembayaran pajak. Dengan modal yang besar, berarti pengembalian yang harus diperoleh diharapkan besar, tidak ada perusahaan yang menginginkan mengalami kerugian, sehingga manajemen perusahaan ditugaskan mengelola laba yang diperoleh dari penjualan tersebut sebaik mungkin yang menyebabkan terjadinya perencanaan pajak yang berakhir pada tindakan tax avoidance (Purwanti \& Sugiyarti, 2017).

\section{SIMPULAN}

Berdasarkan hasil analisis data dan pembahasan yang telah diuraikan, maka dapat ditarik simpulan bahwa pengungkapan corporate social responsibility tidak berpengaruh pada tax avoidance, yang artinya banyak sedikitnya item CSR yang diungkapkan oleh perusahaan tidak dapat memengaruhi perusahaan dalam melakukan tindakan tax avoidance. Perusahaan manufaktur dalam kegiatan operasionalnya tidak menimbulkan dampak besar terhadap kerusakan alam, namun dampaknya dirasakan oleh masyarakat sekitar lokasi perusahaan beroperasi. Good corporate governanace dalam penelitian ini dengan proksi yang terpilih yaitu kepemilikan manajerial dan kepemilikan institusional berpengaruh negatif pada tax avoidance. Sales growth berpengaruh positif pada tax avoidance. Hal ini berarti semakin tinggi tingkat sales growth perusahaan, maka praktik tax avoidance akan meningkat.

Berdasarkan simpulan yang telah diuraikan, maka saran yang dapat disampaikan adalah bagi penelitian selanjutnya dapat melakukan penelitian kembali di perusahaan sektor lainnya seperti melakukan penelitian pada perusahaan sektor pertambangan yang lebih berpotensi terhadap kerusakan alam. Pada penelitian ini memiliki nilai adjusted $R$ Square yang rendah yaitu sebesar 9,2 persen menunjukkan bahwa adanya keterbatasan variabel independen yang digunakan dalam menjelaskan variabel dependen (tax avoidance). Bagi perusahaan agar menerapkan mekanisme good corporate governance sehingga segala kebijakan dan tindakan yang diambil oleh pihak pengelola perusahaan tidak merugikan perusahaan dan sesuai dengan kepentingan pemegang saham, khususnya terkait dengan kebijakan dalam pembayaran pajak. Peneliti selanjutnya dapat menggali informasi terkait pengungkapan CSR menggunakan metode lain seperti melihat atau observasi langsung terkait implementasi CSR yang dilakukan perusahaan.

\section{REFERENSI}

Ajzen, I. (1991). The Theory of Planned Behavior. Organizational Behavior and Human Decison Processes, 50(1), 179-211.

Ayuningtyas, N. P. W., \& Sujana, I. K. (2018). Pengaruh Proporsi Komisaris Independen, Leverage, Sales Growth Dan Profibilitas Pada Tax Avoidance. E-Jurnal Akuntansi Universitas Udayana, 25(3), 1884-1912.

Charisma, R. B., \& Dwimulyani, S. (2019). Pengaruh Struktur Kepemilikan terhadap Tindakan Penghindaran Pajak dengan Kualitas Audit sebagai Variabel Moderating. Prosiding Seminar Nasional, 1-10. 
Chen, S. (2010). Client Importance, Institutional Improvements, and Audit Quality in China: An Office and Individual Auditor Level Analysis. The Accounting Review, 85(1), 127-158.

Chen, Z., Cheok, C. K., \& Rasiah, R. (2016). Corporate Tax Avoidance and Performance: Evidence from China's Listed Companies. Institutions and Economies, 8(3), 61-83.

Darmayanti, P. P. B., \& Merkusiwati, N. K. L. A. (2019). Pengaruh Ukuran Perusahaan, Profitabilitas, Koneksi Politik dan Pengungkapan Corporate Social Responsibility Pada Tax Avoidance. E-Jurnal Akuntansi Universitas Udayana, 26(3), 1992-2019.

Dewanti, I. G. A. D. C., \& Sujana, I. K. (2019). Pengaruh Ukuran Perusahaan, Corporate Social Responsibility, Profitabilitas dan Leverage pada Tax Avoidance. E-Jurnal Akuntansi, 28(1), 377-406.

Dewinta, I. A. R., \& Setiawan, P. E. (2016). Pengaruh Ukuran Perusahaan, Umur Perusahaan, Profitabilitas, Leverage dan Pertumbuhan Penjualan terhadap Tax Avoidance. E-Jurnal Akuntansi Universitas Udayana, 14(3), 1584-1613.

Fadhila, N. S., Pratomo, D., \& Yudowati, S. P. (2017). Pengaruh Kepemilikan Manajerial, Komisaris Independen dan Komite Audit Terhadap Tax Avoidance. E-Jurnal Akuntani Universitas Udayana, 21(3), 1803-1820.

Fadhilah, R. (2014). Pengaruh Good Corporate Governance Terhadap Tax Avoidance (Studi Empiris Pada Perusahaan Manufaktur yang Terdaftar di BEI 2009-2011). E-Journal UNP, 2(1), 1-22.

Femitasari, L. (2014). Pengaruh Proporsi Dewan Komisaris Independen, Kepemilikan Institusional dan Corporate Social Responsibility terhadap Agresivitas Pajak. Jurnal Katolik Widya Mandala Surabaya.

Hanlon, M., \& Heitzman, S. (2010). A Review of Tax Research. Journal of Accounting and Economics, 50, 127-178. https://doi.org/10.1016/j.jacceco.2010.09.002

Hoque, M. K. (2017). International Tax Avoidance and Tax Havens. Journal International of Cost and Management, 45(1), 63-67.

Jacob, F. O. F. (2014). An Empirical Study of Tax Evasion and Tax Avoidance : A Critical Issue in Nigeria Economic Development. Journal of Economics and Sustainable Development, 5(18), 22-27.

Jamei, R. (2017). Tax Avoidance and Corporate Governance Mechanisms: Evidence from Tehran Stock Exchange. International Journal of Economics and Financial, 7(4), 638-644.

Januari, D. M. D., \& Suardikha, I. M. S. (2019). Pengaruh Corporate Social Responsibility , Sales Growth, dan Profitabilitas Terhadap Tax Avoidance. E-Jurnal Akuntansi Universitas Udayana, 27(3), 1653-1677.

Jingga, V., \& Lina, L. (2017). Factors Influencing Tax Avoidance Activity : An Empirical Study from Indonesia Stock Exchange. Indian Pasific Journal of Accounting and Finance (IPJAF), 1(1), 17-25.

Kementrian Keuangan Republik Indonesia Direktorat Jendral Pajak. (2019). Laporan Kinerja Direktorat Jendral Pajak. Retrieved from Kementerian Keuangan Republik Indonesia Direktorat Jendral Pajak website: https://www.pajak.go.id/sites/default/files/2019-05/LAKIN_DJP 2018.pdf. Diakses 17 Juni 2019. 
Kusumawardani, I. (2017). Faktor-Faktor yang Memengaruhi Pengungkapan Corporate Social Responsibility. E-Jurnal Akuntansi Universitas Udayana, 19(1), 741-770.

Lanis, R., \& Richardson, G. (2011). The Effect of Board of Director Composition on Corporate Tax Aggressiveness. Journal of Accounting and Public Policy, 30(1), 50-70. https://doi.org/10.1016/j.jaccpubpol.2010.09.003

Lanis, R., \& Richardson, G. (2012). Corporate Social Responsibility and Tax Aggressiveness: An Empirical Analysis. Journal of Accounting and Public Policy, 31(1), 86-108. https://doi.org/10.1016/j.jaccpubpol.2011.10.006

Lestari, G. A. W., \& Putri, I. G. A. . A. D. (2017). Pengaruh Corporate Governance, Koneksi Politik dan Leverage Terhadap Penghindaran Pajak. E-Jurnal Akuntani Universitas Udayana, 18(3), 2028-2054.

Lim, Y. (2011). Tax Avoidance, Cost of Debt and Shareholder Activism: Evidence from Korea. Journal of Banking and Finance, 35, 456-470. https://doi.org/10.1016/j.jbankfin.2010.08.021

Makhfudloh, F., Herawati, N., \& Wulandari, A. (2018). Pengaruh Corporate Social Responsibility terhadap Perencanaan Agresivitas Pajak. Jurnal Akuntansi dan Bisnis, 18(1), 48-60.

Mulyani, S., Darminto, \& Endang, M. G. W. (2014). Pengaruh Karakteristik Perusahaan, Koneksi Politik dan Reformasi Perpajakan terhadap Penghindaran Pajak (Studi Pada Perusahaan Manufaktur yang Terdaftar di Bursa Efek Tahun 2008-2012). Jurnal Mahasiswa Perpajakan Universitas Brawijaya, 1(2), 1-9.

Oktaviyani, R., \& Munandar, A. (2017). Effect of Solvency, Sales Growth, and Institutional Ownership on Tax Avoidance with Profitability as Moderating Variables in Indonesian Property and Real Estate Companies. Binus Business Review, 8(3), 183-188. https://doi.org/10.21512/bbr.v8i3.3622

Park, S. (2017). Corporate Social Responsibility and Tax Avoidance: Evidence from Korean Firms. The Journal of Applied Business Research, 33(6), 1059-1068. https://doi.org/10.19030/jabr.v33i6.10045

Park, S. (2018). Related Party Transactions and Tax Avoidance of Business Groups. Sustainability (Switzerland), 10, 1-14. https://doi.org/10.3390/su10103571

Pradipta, D. H., \& Supriyadi. (2015). Pengaruh Corporate Social Responsibility (CSR), Profitabilitas, Leverage, dan Komisaris Independen Terhadap Praktik Penghindaran Pajak. Kompartemen Jurnal Ilmiah Akuntansi, XV(1), 1-25.

Praditasari, N. K. A., \& Setiawan, P. E. (2017). Pengaruh Good Corporate Governance, Ukuran Perusahaan, Leverage dan Profitabilitas Pada Tax Avoidance. E-Jurnal Akuntansi Universitas Udayana, 19, 1229-1258.

Pradnyawati, N. P., \& Suprasto, H. B. (2019). Pengaruh Good Corporate Governance Terhadap Agresivitas Pajak dengan Voluntary Disclosure Sebagai Variabel Pemoderasi. E-Jurnal Akuntansi Universitas Udayana, 26(2), 1132-1160.

Purwanti, S. M., \& Sugiyarti, L. (2017). Pengaruh Intensitas Aset Tetap , Pertumbuhan Penjualan dan Koneksi Politik terhadap Tax Avoidance. Jurnal Riset Akuntansi dan Keuangan, 5(3), 1625-1641.

Purwantini, H. (2017). Minimizing Tax Avoidance by Using Conservatism 
Accounting through Book Tax Differences. Case Study in Indonesia. International Journal of Research in Business and Social Science, 6(5), 55-67.

Puspita, D., \& Febrianti, M. (2017). Faktor-Faktor yang Memengaruhi Penghindaran Pajak pada Perusahaan Manufaktur di Bursa Efek Indonesia. Jurnal Bisnis dan Akuntansi, 19(1), 38-46. https://doi.org/10.34208/jba.v19i1.63

Ramila, Rambe, P. A., \& Ruwanti, S. (2016). Pengaruh Corporate Social Responsibility, Profitabilitas, Leverage dan Capital Intensity Terhadap Agresivitas Pajak Pada Perusahaan Manufaktur yang Terdaftar Di Bursa Efek Indonesia Tahun 2013 - 2016. Jurnal Ekonomi UMRAH, 1-15.

Sugihato, D. (2014). Prahara Pajak Raja Otomotif. Retrieved from Tempo.co website: https://investigasi.tempo.co/toyota/. Diakses 18 Juli 2019.

Thai Ha, N. T., \& Quyen, P. G. (2017). The Relationship Between State Ownership and Tax Avoidance Level : Empirical Evidence From Vietnamese Firms. Journal of Asian Business Strategy, 7(1), 1-12. https://doi.org/10.18488/journal.1006/2017.7.1/1006.1.1.12

Ulfa, T. N. M. (2016). Pengaruh Profitabilitas, Mekanisme Good Corporate Governance dan Pengungkapan Corporate Social Responsibility terhadap Tindakan Pajak Gresif (Syudi pada Perusahaan Pertambangan yang terdaftar di Bursa Efek Indonesia periode 2010-2014). Journal of Accouting and Investment, 1-25.

Watson, L. (2015). Corporate Social Responsibility, Tax Avoidance, and Earnings Performance. The Journal of the American Taxation Association, 37(2), 1-22. https://doi.org/10.2308/atax-51022

Wiguna, I. P. P., \& Jati, I. K. (2017). Pengaruh Corporate Social Responsibility, Preferensi Risiko Eksekutif, dan Capital Intensity Pada Penghindaran Pajak. E-Jurnal Akuntansi Universitas Udayana, 21(1), 418-446. 